\title{
PERILAKU KONSUMEN DALAM KEPUTUSAN PEMBELIAN MARTABAK ITANG DI PAKOWA MANADO
}

\author{
Peggy Nurhayati Suleman \\ Leonardus R. Rengkung \\ Juliana R. Mandei
}

\begin{abstract}
This study aimed to determine the consumer behavior based on individual, environmental, and marketing strategy factors in the buying decision of Martabak Itang in Pakowa, Manado. This study was expected to be the source of information to entrepreneurs about the consumers behavior in buying Martabak Itang in Pakowa, Manado, so that companies can determine and improve the strategy in dealing with the competition.The data used in this study were primary data and secondary data. The sampling method in this study was Accidental Sampling, which was taking the sample that accidentally met with the researcher. The total of sample taken in this study was 60 people. The sampling process was conducted in 6 days, which was the number of samples taken was 10 buyers for day for a week, from Monday until Saturday. The result of this study showed that individual factors measured by need and motivation did not affect the buying decision. Environmental factors measured by family and friends influencethe buying decision. While marketing strategy factors measured by product, price, promotion, location, and service influencethe buying decision. *lr**
\end{abstract}

Keywords: consumer behavior, purchasing decisions, Martabak Itang, Pakowa, Manado.

\begin{abstract}
ABSTRAK
Penelitian ini bertujuan untuk mengetahui perilaku konsumen berdasarkan faktor individu, lingkungan dan strategi pemasaran dalam keputusan pembelian Martabak Itang di Pakowa Manado. Manfaat penelitian ini diharapkan menjadi bahan informasi kepada pengusaha tentang perilaku konsumen dalam keputusan pembelian Martabak Itang di Pakowa Manado agar perusahaan dapat menentukan dan meningkatkan strategi dalam menghadapi tingkat persaingan. Data yang digunakan dalam peneltian ini berbentuk data primer dan data sekunder. Metode pengambilan sampel dalam penelitian ini dilakukan dengan Accidental Sampling yaitu dengan mengambil sampel secara kebetulan bertemu dengan peneliti. Jumlah sampel yang diambil dalam penelitian ini adalah 60 orang. Proses pengambilan sampel dilakukan selama 6 hari dengan jumlah sampel yang diambil sebanyak 10 orang pembeli setiap hari selama satu minggu yaitu dari hari Senin sampai hari Sabtu. Hasil penelitian menunjukkan bahwa faktor individu yang diukur berdasarkan kebutuhan dan motivasi tidak mempengaruhi keputusan pembelian. faktor lingkungan yang diukur berdasarkan keluarga dan teman mempengaruhi keputusan pembelian. Sedangkan faktor strategi pemasaran yang diukur berdasarkan produk, harga, promosi, lokasi dan pelayanan mempengaruhi keputusan pembelian. * $* r *$.
\end{abstract}

Kata kunci: perilaku konsumen, keputusan pembelian, Martabak Itang, Pakowa, Manado. 


\section{PENDAHULUAN}

\section{Latar Belakang}

Industri kuliner merupakan sektor yang strategis bagi ekonomi Indonesia dan pertumbuhan kuliner sangat berkembang pesat, semakin diminati oleh masyarakat. Industri kuliner adalah suatu usaha perdagangan yang dilakukan oleh sekelompok orang di bidang makanan yang terorganisasi agar bisa mendapatkan laba dengan cara memproduksi dan menjual barang dan jasa untuk memenuhi kebutuhan masyarakat (Gunawan, 2011). Selanjutnya, Bachrul (2013), mendefinisikan industri kuliner adalah industri yang mengolah bahan mentah menjadi barang jadi yang berupa makanan dan minuman.

Perkembangan industri kuliner ini dimulai dari yang berskala kecil selain itu setiap industri harus memiliki inovasi untuk dapat bersaing dan harus memiliki daya tarik suatu produk yang dihasilkannya (Bachrul, 2013). Peluang industri kuliner saat ini memang terus berkembang dan menjadi daya tarik tersendiri. Mengingat untuk memulai suatu industri kuliner membutuhkan modal selain itu harus didukung dengan kondisi bahwa industri kuliner memiliki permintaan yang banyak dari konsumen. Beragam industri kuliner yang berskala kecil mudah ditemui mulai dari pinggir jalan sampai ke restoran yang berada di tempat perbelanjaan.

Perkembangan industri ini mengalami peningkatan dari tahun ke tahun. Data BPS tahun 2016 menyatakan bahwa pertumbuhan industri kuliner mencapai $8,2-8,5 \%$ pada tahun 2016. Hal ini membuktikan kuliner sangat diminati oleh masyarakat baik dalam aspek permintaan maupun produksi.

Salah satu industri kuliner yang memiliki daya tarik konsumen adalah makanan martabak. Martabak adalah salah satu makanan yang disukai banyak orang yang terbuat dari campuran tepung dan telur yang sudah diolah sedemikian rupa. Martabak ini ada berbagai jenis diantaranya martabak asin, martabak manis, martabak mini, martabak hitam.

Di Sulawesi Utara khususnya Kota Manado martabak ini menjadi makanan keluarga karena biasa disantap bersama keluarga dan martabak yang sedang berkembang pesat di Kota Manado adalah Martabak Itang. Martabak Itang terletak di Pakowa Kota Manado merupakan salah satu cabang Martabak Itang yang didirikan pada tanggal 22 September 2016. Nama Martabak Itang sendiri di ambil dari bahasa sehari-hari Manado "Itang" yang berarti Hitam. Pelanggan Martabak Itang di Pakowa bukan hanya dari masyarakat sekitar wilayah Pakowa namun juga dikunjungi oleh masyarakat dari luar wilayah Pakowa. Meskipun di dalam Kota Manado memiliki usaha sejenis martabak yang lain, namun Martabak Itang ini tetap memiliki pelanggan, karena varian yang ditawarkan Martabak Itang cukup memiliki daya tarik tersendiri untuk bisa bersaing dengan usaha sejenisnya.

Para pengusaha kuliner menghadapi persaingan yang kompetitif, sehingga dituntut untuk mencermati perilaku konsumen dan faktor-faktor yang mempengaruhi keputusan pembelian. Hal tersebut sesuai dengan konsep pemasaran yang menyebutkan bahwa kesuksesan suatu perusahaan ditentukan oleh usaha dalam memenuhi kebutuhan konsumen, sehingga memberikan kepuasan yang diinginkan (Schiffman dan Kanuk, 2008).

Karakteristik konsumen akan mempengaruhi perilaku konsumen dalam melakukan pembelian, sehingga berpengaruh pula terhadap produk atau jasa apa yang akan dibeli. Keputusan pembelian merupakan tahapan dimana kosumen mempertimbangkan beberapa faktor dan alasan yang memperkuat untuk memutuskan membeli suatu produk (Schiffman dan Kanuk, 2008). Perilaku konsumen merupakan hal-hal yang mendasari konsumen untuk membuat keputusan pembelian proses yang mendasari pengambilan keputusan produk yaitu pengenalan masalah (problem recognize), pencarian informasi (information scure), mengevaluasi alternativ (alternative evalution), keputusan pembelian, evaluasi paskah pembelian. Selain itu, berdasarkan keputusan pembelian juga di pengaruhi oleh faktor-faktor yang dapat menimbulkan tanggapan konsumen terhadap suatu produk. 
Memahami faktor-faktor yang mempengaruhi konsumen dalam membeli Martabak Itang di Pakowa Manado merupakan informasi pasar yang sangat penting. Informasi ini dilakukan sebagai bahan masukan untuk merencanakan dan mengembangkan produk dengan baik. Oleh sebab itu Martabak Itang Pakowa perlu memahami faktor-faktor yang mempengaruhi konsumen dalam keputusan pembelian agar dapat mempertahankan konsumenya.

\section{Rumusan Masalah}

Berdasarkan uraian latar belakang, maka yang menjadi rumusan masalah dalam penelitian ini adalah apakah perilaku konsumen dilihat dari faktor individu, lingkungan dan strategi pemasaran berpengaruh dalam keputusan pembelian Martabak Itang di Pakowa Manado?

\section{Tujuan Penelitian}

Penelitian ini bertujuan untuk mengetahui perilaku konsumen berdasarkan faktor konsumen individu, lingkungan dan strategi pemasaran dalam keputusan pembelian Martabak Itang di Pakowa Manado.

\section{Manfaat Penelitian}

Manfaat penelitian ini diharapkan menjadi bahan informasi kepada pengusaha tentang perilaku konsumen dalam keputusan pembelian Martabak Itang di Pakowa Manado agar perusahaan dapat menentukan dan meningkatkan strategi dalam menghadapi tingkat persaingan.

\section{METODOLOGI PENELITIAN}

\section{Waktu dan Tempat Penelitian}

Penelitian ini dilaksanakan pada bulan Februari sampai bulan April 2018, Tempat penelitian digerai Martabak Itang Pakowa Kecamatan Wanea.

\section{Metode Pengumpulan Data}

Data yang digunakan dalam peneltian ini berbentuk data primer dan data sekunder. Data primer yang diambil terkait dengan faktor- faktor perilaku konsumen yaitu faktor konsumen individu, lingkungan dan strategi pemasaran. Pengambilan data dilakukan secara survei dengan wawancara langsung terhadap konsumen Martabak Itang Manado dengan menggunakan daftar pertanyaan. Data sekunder yang diambil terkait dengan deskripsi usaha martabak itang dan ruang lingkup bidang usaha.

\section{Metode Pengambilan Sampel}

Populasi dari penelitian ini adalah para konsumen Martabak Itang. Metode pengambilan sampel dalam penelitian ini dilakukan dengan Accidental Sampling yaitu dengan mengambil sampel secara kebetulan bertemu dengan peneliti. Jumlah sampel yang akan diambil dalam penelitian ini adalah 60 orang. Proses pengambilan sampel dilakukan selama 6 hari dengan jumlah sampel yang diambil sebanyak 10 orang pembeli setiap hari selama satu minggu yaitu dari hari Senin sampai hari Sabtu.

\section{Konsep Pengukuran Variabel}

Variabel yang diukur dalam penelitian ini terdiri dari:

1. Konsumen (Individu)
a) Kebutuhan
b) Motivasi

2. Lingkungan
a) Keluarga
b) Teman

3. Strategi Pemasaran
a) Produk
b) Harga
c) Promosi
d) Lokasi
e) Pelayanan

\section{Metode Analisis Data}

Penelitian ini menggunakan teknik analisis deskriptif. Analisis deskriptif digunakan untuk data yang bersifat kualitatif dan disajikan dalam bentuk tabulasi. Hasil yang diperoleh kemudian dipersentasekan berdasarkan jumlah responden.

Analisis data dilakukan dengan cara membuat tabulasi distribusi responden dari setiap variabel yang diteliti untuk mengetahui perilaku konsumen dilihat dari konsumen 
individu, lingkungan dan strategi pemasaran dalam keputusan pembelian Martabak Itang di Pakowa Manado yang diukur berdasarkan skala Likert.

\section{Skala Likert}

Skala likert digunakan untuk mengukur sikap, pendapat, dan persepsi seseorang atau kelompok orang tentang fenomena seseorang, Sunyoto (2012). Dalam skala likert, maka variabel yang akan diukur dijabarkan menjadi indikator variabel. Kemudian indikator tersebut dijadikan sebagai titik tolak untuk menyusun item-item instrument yang dapat berupa pernyataan - pernyataan. Dalam penelitian ini di susun 15 pernyataan dengan total responden 60 orang. Jawaban setiap instrument yang menggunakan skala likert, yang berupa kata kata, antara lain:

$$
\begin{array}{ll}
\mathrm{SS} & =\text { Sangat Setuju } \\
\mathrm{S} & =\text { Setuju } \\
\mathrm{N} & =\text { Netral } \\
\mathrm{TS} & =\text { Tidak Setuju } \\
\mathrm{STS} & =\text { Sangat Tidak Setuju }
\end{array}
$$

Bila:

$\begin{array}{ll}\text { SS diberi skor } & =5 \\ \text { S diberi skor } & =4 \\ \text { N diberi skor } & =3 \\ \text { TS diberi skor } & =2 \\ \text { STS diberi skor } & =1\end{array}$

Dengan cara perhitungan skor masing masing pernyataan:

Jumlah skor tiap kriteria $=$ capaian skor $\mathrm{X}$ jumlah responden.

$$
\begin{aligned}
& \text { S5 }=5 \text { X 60 }=300 \\
& \text { S4 }=4 \text { X 60 }=240 \\
& \text { S3 }=3 \times 60=180 \\
& \text { S2 }=2 \text { X 60 }=120 \\
& \text { S1 }=1 \text { X } 60=60
\end{aligned}
$$

Jumlah skor ideal untuk setiap pernyataan skor tertinggi $=300$ (sangat setuju), jumlah skor terendah $=60$ (sangat tidak setuju)

Dengan interpretasi nilai:

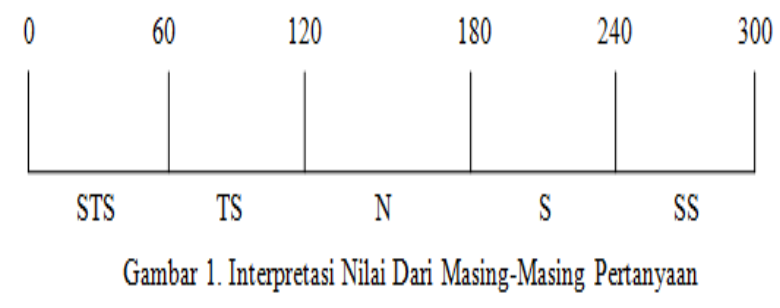

Cara perhitungan skor keseluruhan untuk mengetahui perilaku konsumen:

Jumlah skor seluruh kriterium = capaian jumlah skor $\mathrm{X}$ jumlah responden $\mathrm{X}$ instrumen pertanyaan Untuk:

$$
\begin{aligned}
& \text { S5 }=5 \times 60 \times 15=4500 \\
& S 4=4 \times 60 \times 15=3600 \\
& S 3=3 \times 60 \times 15=2700 \\
& S 2=2 \times 30 \times 15=1080 \\
& S 1=1 \times 60 \times 15=900
\end{aligned}
$$

Jumlah skor ideal untuk keseluruhan pernyataan $=4500$ (sangat setuju) Jumlah skor rendah $=900$ (sangat tidak setuju)

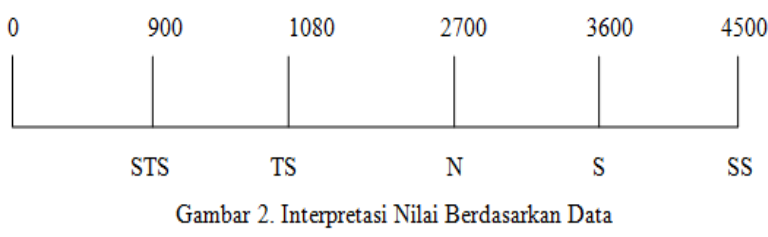

Analisis dengan menggunakan skala pengukuran Likert Scale. Adalah sebagai berikut:

$$
\text { Perilaku konsumen }=\frac{\text { Jumlah Skor Hasil Pengumpulan Data }}{\text { Jumlah skor ideal (tertinggi) }} \times 100 \%
$$

Dengan interprestasi nilai:

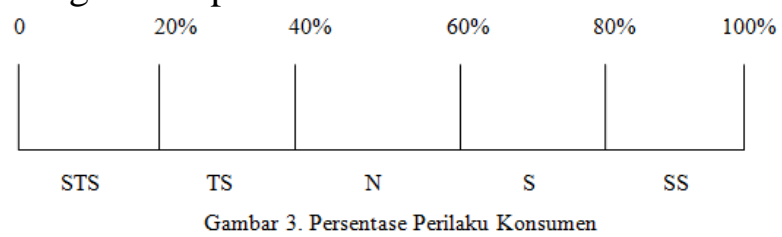

Keterangan kriteria interpretasi skor perilaku konsumen:

$$
\begin{array}{ll}
\text { Angka 0\% }-20 \% & =\text { Sangat Tidak Setuju } \\
\text { Angka 20\% }-40 \% & =\text { Tidak Setuju } \\
\text { Angka 40\%-60\% } & =\text { Netral } \\
\text { Angka 60\% }-80 \% & =\text { Setuju } \\
\text { Angka } 80 \%-100 \% & =\text { Sangat Setuju }
\end{array}
$$

\section{HASIL DAN PEMBAHASAN}

\section{Deskripsi Umum Wilayah Penelitian}

\section{Deskripsi Usaha Martabak Itang}

Martabak Itang merupakan usaha yang didirikan pada tahun 2016 oleh Bapak Wahyu Suryowidodo yang juga merupakan pemilik usaha tersebut. Usaha ini mulai beroperasi di 
Pakowa Manado dan sampai sekarang usaha ini masih berlokasi di tempat tersebut dan juga sudah membuka cabang di Komo, Malalayang, Maumbi dan Bitung. Lokasi penjualan yang dimiliki oleh Maratabak Itang di Pakowa Manado ini dapat dikatakan strategis karena berada dekat dengan jalan raya dan dapat dilalui alat transportasi dengan mudah. Oleh karena itu, dengan lokasi strategis yang dimiliki oleh Martabak Itang di Pakowa Manado sehingga dapat menjangkau para konsumen martabak untuk membeli produk tersebut serta dapat mendukung kelancaran usaha.

Usaha pembuatan Martabak ini menjadi pilihan karena Bapak Wahyu melihat peluang yang cukup besar untuk menjalankan usaha ini karena di daerah tempat tinggalnya memiliki jumlah penduduk yang padat. Pada awalnya Bapak Wahyu memulai usaha ini secara kecil-kecilan bersama keluarganya. Keahlian membuat Martabak Itang ini di peroleh Bapak Wahyu dengan mempelajarinya sendiri. Terbukti pilihan usaha ini sangat tepat karena seiring berjalannya waktu jumlah permintaan terhadap produk yang dihasilkan terus meningkat dan kini usaha Martabak Itang semakin berkembang.

\section{Ruang Lingkup Bidang Usaha}

Martabak Itang merupakan usaha yang bergerak dalam pembuatan Martabak Manis. Martabak Itang yang berada di daerah Pakowa ini sangat ramai oleh para pembeli karena rasa dan warnanya yang khas dan terbuat dari berbagai macam adonan khusus, cita rasanya yang enak, pelayanannya sangat ramah dan sopan, dan tempatnya yang strategis. Kemasan yang di pakai oleh Martabak Itang sendiri terbuat dari kardus yang menarik berwarna hitam, selain itu promosi yang dilakukan oleh Martabak Itang melalui media sosial facebook dan instagram.

Lokasi Martabak Itang berada di Pakowa Kota Manado, tidak hanya di Pakowa Martabak Itang juga membuka cabang di Komo, Malalayang, Maumbi dan Bitung.
Martabak Itang yang berada di Pakowa adalah tempat usaha yang pertama di buka oleh Bapak Wahyu. Tetapi lokasi ini kurang memadai, seperti tempat parkir yang tidak di sediakan.

\section{Karakteristik Konsumen}

Responden yang digunakan dalam penelitian ini adalah responden yang sedang membeli Martabak Itang. Karakteristik umum responden dijelaskan oleh jenis kelamin, usia, pekerjaan dan pendapatn. Deskripsi karakteristik responden disajikan sebagai berikut:

\section{Jenis Kelamin}

Tabel 1 dapat dilihat sebaran jenis kelamin konsumen sebagai responden Martabak Itang di Pakowa Manado. Pada tabel tersebut dapat dijelaskan bahwa paling banyak responden adalah berjenis kelamin perempuan dengan jumlah 37 orang $(61,7 \%)$, sedangakan terdapat 23 orang berjenis kelamin laki-laki $(38,3 \%)$.

Tabel 1. Karakteristik Jenis Kelamin Responden

\begin{tabular}{clcc}
\hline No & Jenis Kelamin & Orang & Persentase $(\%)$ \\
\hline 1. & Laki-laki & 23 & 38,3 \\
2. & Perempuan & 37 & 61,7 \\
\hline & Total & 60 & 100
\end{tabular}

\section{Umur}

Umur merupakan salah satu faktor yang mempengaruhi keputusan pembelian dalam membuat keputusan pembelian suatu produk dan kemampuan konsumen untuk memilih dan mengidentifikasi arti produk bagi konsumen. Pada Tabel 2 berikut dijelaskan tentang sebaran umur konsumen yang membeli produk Martabak Itang di Pakowa Manado.

Tabel 2. Karakteristik Umur Responden

\begin{tabular}{cccc}
\hline No & Umur & Orang & Persentase $(\%)$ \\
\hline 1. & $17-29$ & 37 & 61,7 \\
2. & $30-41$ & 20 & 33,3 \\
3. & $42-53$ & 2 & 3,3 \\
4. & $54-65$ & 1 & 1,7 \\
\hline & Total & 60 & 100 \\
\hline
\end{tabular}


Tabel 2 menunjukkan bahwa umur konsumen yang paling banyak pada sebaran umur 17 - 29 tahun berjumlah 37 orang $(61,7 \%)$, diikuti umur $30-41$ tahun yang berjumlah 20 orang $(33,3 \%)$ dan umur $42-$ 53 tahun berjumlah 2 orang $(3,3 \%)$. Sedangkan konsumen yang berumur $54-65$ tahun berjumlah hanya 1 orang $(1,7 \%)$. Ini menunjukan bahwa seluruh konsumen yang membeli produk Martabak Itang di Pakowa Manado berada pada masa usia yang produktif.

\section{Pekerjaan}

Tingkat pekerjaan juga akan menunjukkan status sosial yang akan mempengaruhi seseorang dalam pengambilan keputusan pembelian. Berikut Tabel 3 yang menunjukkan tingkat pekerjaan konsumen yang membeli Martabak Itang di Pakowa Manado.

Tabel 3. Karakteristik Pekerjaan Responden

\begin{tabular}{clcc}
\hline No & Pekerjaan & Orang & Persentase (\%) \\
\hline 1. & Pelajar/Mahasiswa & 12 & 20 \\
2. & Ibu Rumah Tangga & 5 & 8,3 \\
3. & PNS/ABRI & 9 & 15 \\
4. & Wiraswasta & 21 & 35 \\
5. & Swasta & 13 & 21,7 \\
\hline & Total & 60 & 100 \\
\hline
\end{tabular}

Tabel 3 menunjukkan bahwa pekerjaan konsumen yang paling banyak pada sebaran pekerjaan wiraswasta berjumlah 21 orang (35\%) diikuti swasta yang berjumlah 13 orang $(21,7 \%)$, Pelajar/Mahasiswa yang berjumlah 12 orang (20\%), PNS/ABRI 9 orang (15\%). Sedangkan ibu rumah tangga hanya berjumlah 5 orang $(7,3 \%)$ ini menunjukkan bahwa Martabak Itang di Pakowa Manado cukup diminati oleh berbagai kalangan dari berbagai jenis pekerjaan, khususnya bagi mereka yang ingin mengkonsumsi martabak karena martabak merupakan makanan yang siap saji. Tingkat pekerjaan sebagai wiraswasta menjadi pelanggan Martabak Itang di Pakowa Manado paling dominan, hal ini disebabkan dari penghasilannya yang cukup untuk membeli produk Martabak Itang di Pakowa Manado.

\section{Pendapatan}

Tingkat pendapatan juga akan mempengaruhi seseorang dalam membeli suatu produk. Berikut Tabel 4 yang menunjukan tingkat pekerjaan konsumen yang membeli Martabak Itang di Pakowa Manado.

Tabel 4. Karakteristik Pendapatan Responden

\begin{tabular}{clcc}
\hline No & Pendapatan Perbulan & Orang & $\begin{array}{c}\text { Persentase } \\
(\%)\end{array}$ \\
\hline 1. & $500.000-1.625 .000$ & 15 & 25 \\
2. & $1.625 .000-2.750 .000$ & 24 & 40 \\
3. & $2.750 .000-3.875 .000$ & 20 & 33,3 \\
4. & $3.875 .000-5.000 .000$ & 1 & 1,7 \\
\hline & Total & 60 & $100 \%$ \\
\hline
\end{tabular}

Tabel 4 menunjukkan bahwa pendapatan konsumen yang paling banyak pada sebaran pendapatan $1.625 .000-$ 2.750 .000 berjumlah 24 orang $(40 \%)$, diikuti pendapatan $2.750 .000-3.875 .000$ yang berjumlah 20 orang $(33,3 \%)$, dan pendapatan $500.000-1.625 .000$ berjumlah 15 orang (25\%). Sedangkan 3.875.000 - 5.000.000 berjumlah hanya 1 orang $(1,7 \%)$. Ini menunjukkan bahwa seluruh konsumen yang membeli produk Martabak Itang di Pakowa Manado memiliki pendapatan yang cukup untuk memenuhi kebutuhan dan keinginan mereka.

\section{Faktor - Faktor Yang Mempengaruhi Keputusan Pembelian}

Faktor-faktor yang mempengaruhi keputusan pembelian diukur berdasarkan individu, lingkungan, strategi pemasaran. Pengukuran berdasarkan skala 1 sampai 5 . Hasil penelitian tentang perilaku konsumen terkait dengan faktor-faktor tersebut dijelaskan sebagai berikut.

\section{Individu}

Individu yaitu pilihan untuk membeli barang/jasa dipengaruhi oleh hal-hal yang ada pada diri konsumen seperti kebutuhan dan 
motivasi. Konsumen yang digunakan dalam penelitian ini adalah konsumen yang sedang membeli Martabak Itang di Pakowa Manado.

\section{Rekapitulasi Perilaku Konsumen Dalam Keputusan Pembelian Martabak Itang dari Faktor Individu}

Tabel 5 menunjukkan rekapitulasi terhadap jumlah skor pengambilan data pada perilaku konsumen dalam keputusan pembelian dari faktor individu.

\begin{tabular}{llccc} 
Tabel 5. & $\begin{array}{c}\text { Rekapitulasi Total Skor, Perilaku Konsumen dan } \\
\text { Interpretasi } \\
\text { Martabak Itang di Pakowa Manado } \\
\text { Individu }\end{array}$ & $\begin{array}{r}\text { Dalam } \\
\text { Keputusan }\end{array}$ & $\begin{array}{r}\text { Pembelian } \\
\text { dari Faktor }\end{array}$ \\
\hline No & $\begin{array}{l}\text { Pertanyaan } \\
\text { Total } \\
\text { Skor }\end{array}$ & $\begin{array}{c}\text { Perilaku } \\
\text { Konsumen }(\%)\end{array}$ & Interpretasi \\
& $\begin{array}{l}\text { Kebutuhan } \\
\text { Produk } \\
\text { Motivasi }\end{array}$ & 161 & 53,7 & Netral \\
& $\begin{array}{l}\text { Mengkonsumsi } \\
\text { Produk }\end{array}$ & 180 & 60 & Netral \\
\hline & & & 56,8 & Netral \\
\hline
\end{tabular}

Tabel 5 menunjukkan bahwa dari seluruh indikator perilaku konsumen dalam keputusan pembelian Martabak Itang dari faktor individu terletak pada angka 56,8\%. Artinya secara keseluruhan perilaku konsumen dalam keputusan pembelian Martabak Itang di Pakowa Manado jika dilihat dari faktor individu tidak mempengaruhi keputusan pembelian. Dan indikator yang memperoleh persentase perilaku konsumen yang tinggi adalah pada motivasi mengkonsumsi produk yaitu sebesar $60 \%$.

\section{Lingkungan}

Lingkungan artinya bahwa pilihan konsumen terhadap barang atau jasa dipengaruhi oleh lingkungan yang mengitarinya. Lingkungan merupakan salah satu faktor yang mempengaruhi keputusan pembelian konsumen. Lingkungan yang mempengaruhi keputusan pembelian konsumen yaitu lingkungan keluarga dan teman.

\section{Rekapitulasi Perilaku Konsumen Dalam Keputusan Pembelian Martabak Itang dari Faktor Lingkungan}

Tabel 6 menunjukkan rekapitulasi terhadap jumlah skor pengambilan data pada perilaku konsumen dalam keputusan pembelian dari faktor lingkungan.

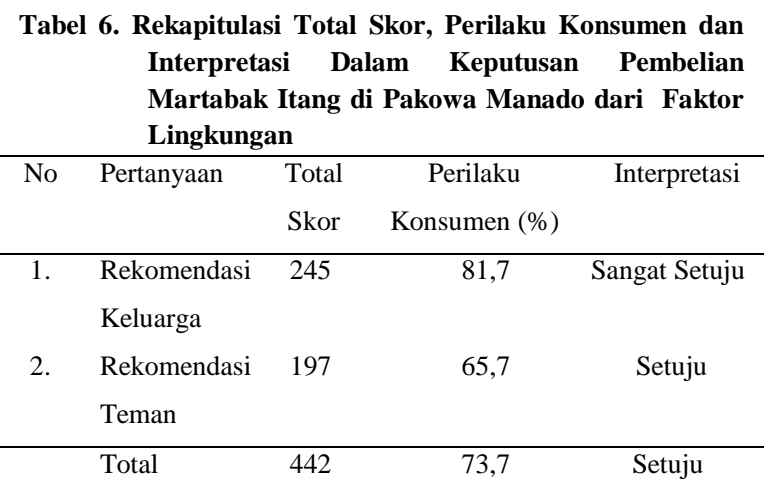

Tabel 6 menunjukkan bahwa dari seluruh indikator perilaku konsumen dalam keputusan pembelian Martabak Itang dari faktor lingkungan terletak pada angka 73,7\%. Dan indikator yang memperoleh persentase perilaku konsumen yang tinggi adalah pada rekomendasi keluarga yaitu sebesar $81,7 \%$ karena memang keluarga merupakan orangorang terdekat konsumen yang sangat mempengaruhi dalam keputusan pembelian.

\section{Strategi Pemasaran}

Strategi Pemasaran yaitu stimuli pemasaran yang dikendalikan oleh pemasar yang dapat mempengaruhi konsumen sehingga menarik konsumen untuk melakukan pembelian.

\section{Produk}

Produk adalah sesuatu yang dapat ditawarkan ke pasar untuk diperhatikan, dipakai, dimiliki, atau dikonsumsikan sehingga dapat memuaskan keinginan atau kebutuhan konsumen. Ada tiga indikator pada sub variabel produk untuk mengukur perilaku konsumen dalam keputusan pembelian Martabak Itang di Pakowa Manado yaitu cita rasa yang enak, variasi topping yang menarik, tekstur produk yang lembut. 


\section{Rekapitulasi Perilaku Konsumen Dalam Keputusan Pembelian Martabak Itang dari Segi Produk}

Tabel 7 menunjukkan rekapitulasi terhadap jumlah skor pengambilan data pada perilaku konsumen dalam keputusan pembelian dari segi produk yang disajikan.

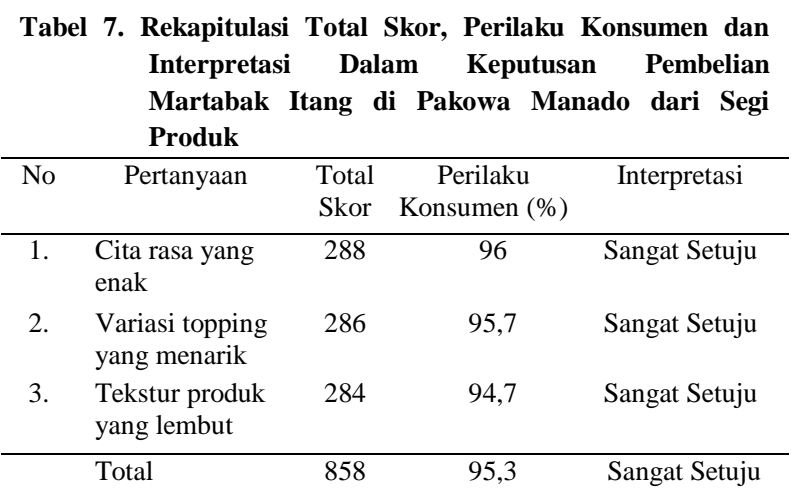

Tabel 7 menunjukkan bahwa dari seluruh indikator perilaku konsumen dalam keputusan pembelian Martabak Itang dari segi produk terletak pada skor 858 dan persentase perilaku konsumen sebesar 95,3\%. Dan indikator yang memperoleh persentase perilaku konsumen yang tinggi adalah pada citarasa yang enak yaitu sebesar $96 \%$. Hal ini menunjukkan bahwa citarasa yang enak sangat mempengaruhi konsumen dalam keputusan pembelian, untuk itu produsen harus mampu mempertahankan citarasa dari martabak itang.

\section{Harga}

Harga adalah jumlah uang dan aspek lain yang mengandung kegunaan tertentu yang diperlukan untuk mendapatkan suatu produk. Ada dua indikator pada sub variabel harga untuk mengukur perilaku konsumen dalam keputusan pembelian Martabak Itang di Pakowa Manado yaitu harga sesuai dengan kualitas produk dan harga terjangkau.

\section{Rekapitulasi Perilaku Konsumen Dalam Keputusan Pembelian Martabak Itang dari Segi Harga}

Tabel 8 menunjukkan rekapitulasi terhadap jumlah skor pengambilan data pada perilaku konsumen dalam keputusan pembelian dari segi harga.
Tabel 8. Rekapitulasi Total Skor Perilaku Konsumen dan Interpretasi Dalam Keputusan Pembelian Martabak Itang di Pakowa Manado dari Segi Harga

\begin{tabular}{llccc}
\hline No & Pertanyaan & $\begin{array}{c}\text { Total } \\
\text { Skor }\end{array}$ & $\begin{array}{c}\text { Perilaku } \\
\text { Konsumen }(\%)\end{array}$ & Interpretasi \\
\hline 1. & $\begin{array}{l}\text { Harga sesuai dengan } \\
\text { kualitas produk }\end{array}$ & 277 & 92,3 & Sangat Setuju \\
$\begin{array}{l}\text { 2. } \\
\text { Harga terjangkau }\end{array}$ & 272 & 90,7 & Sangat Setuju \\
\hline & Total & 549 & 91,5 & Sangat Setuju \\
\hline
\end{tabular}

Tabel 8 menunjukkan bahwa dari seluruh indikator perilaku konsumen dalam keputusan pembelian Martabak Itang dari segi harga terletak pada skor 549 dan persentase perilaku konsumen sebesar 91,5\%. Artinya secara keseluruhan responden sangat setuju terhadap harga yang ditawarkan Martabak Itang dan indikator yang memperoleh persentase perilaku konsumen yang tinggi adalah harga sesuai dengan kualitas produk yaitu sebesar 92,3\%. Harga yang sesuai dengan kualitas produk menjadi daya tarik konsumen dalam keputusan pembelian. Hal ini menunjukkan bahwa harga jual dari Martabak Itang sebanding dengan cita rasa serta variasi topping yang ditawarkan.

\section{Promosi}

Promosi adalah kegiatan yang ditujukan untuk mempengaruhi konsumen agar mengenal produk yang ditawarkan oleh perusahaan sehingga konsumen bersedia untuk membeli produk tersebut. Ada dua indikator pada sub variabel promosi untuk mengukur perilaku konsumen dalam keputusan pembelian Martabak Itang di Pakowa Manado yaitu informasi yang disampaikan iklan jelas dan tepat sasaran dan penggunaan kata yang menarik.

\section{Rekapitulasi Perilaku Konsumen Dalam Keputusan Pembelian Martabak Itang dari Segi Promosi}

Tabel 9 menunjukkan rekapitulasi terhadap jumlah skor pengambilan data pada perilaku konsumen dalam keputusan pembelian dari segi promosi. 
Tabel 9. Rekapitulasi Total Skor Perilaku Konsumen dan Interpretasi Dalam Keputusan Pembelian Martabak Itang di Pakowa Manado dari Segi Promosi

\begin{tabular}{llccc}
\hline No & Pertanyaan & $\begin{array}{c}\text { Total } \\
\text { Skor }\end{array}$ & $\begin{array}{c}\text { Perilaku } \\
\text { Konsume } \\
(\%)\end{array}$ & Interpretasi \\
& & & 90,7 & $\begin{array}{c}\text { Sangat } \\
\text { Setuju }\end{array}$ \\
\hline 1. & $\begin{array}{l}\text { Informasi yang } \\
\text { disampaikan } \\
\text { iklan jelas dan } \\
\text { tepat sasaran }\end{array}$ & & & \\
$\begin{array}{l}\text { 2. } \\
\text { Penggunaan } \\
\text { kata yang } \\
\text { menarik }\end{array}$ & 274 & 91,3 & Sangat \\
& & & Setuju \\
\hline Total & 546 & 91 & Sangat \\
& & & Setuju \\
\hline
\end{tabular}

Tabel 9 menunjukkan bahwa dari seluruh indikator perilaku konsumen dalam keputusan pembelian Martabak Itang dari segi promosi terletak pada skor 546 dan interpretasi perilaku konsumen sebesar 91\%. Perilaku konsumen dalam keputusan pembelian martabak itang di Pakowa Manado juga dipengaruhi oleh strategi pemasaran dari produsen selain harga yang terjangkau, variasi topping yang menarik, promosi martabak itang lewat sosial media juga sangat menarik. Secara keseluruhan responden sangat setuju terhadap promosi yang ditawarkan martabak itang dan indikator yang memperoleh persentase perilaku konsumen yang tinggi adalah penggunaan kata yang menarik yaitu sebesar $91,3 \%$.

\section{Lokasi}

Lokasi usaha dalam menjual suatu produk adalah salah satu keputusan penting yang akan mempengaruhi keberlangsungan usaha. Perusahaan harus memliki tempat yang strategis dalam menjual produknya sehingga dapat dijangkau dengan mudah oleh konsumen. Ada dua indikator pada sub variabel lokasi untuk mengukur perilaku konsumen dalam keputusan pembelian Martabak Itang di Pakowa Manado yaitu lokasi mudah dijangkau, tersedianya halaman parkir.

\section{Rekapitulasi Perilaku Konsumen Dalam Keputusan Pembelian Martabak Itang dari Segi Lokasi}

Tabel 10 menunjukkan rekapitulasi terhadap jumlah skor pengambilan data pada perilaku konsumen dalam keputusan pembelian dari segi lokasi.

Tabel 10. Rekapitulasi Total Skor, Perilaku Konsumen dan Interpretasi Dalam Keputusan Pembelian Martabak Itang di Pakowa Manado dari Segi Lokasi

\begin{tabular}{llccc}
\hline No & Pertanyaan & $\begin{array}{c}\text { Total } \\
\text { Skor }\end{array}$ & $\begin{array}{c}\text { Perilaku } \\
\text { Konsumen } \\
(\%)\end{array}$ & Interpretasi \\
\hline 1. & $\begin{array}{l}\text { Lokasi mudah } \\
\text { dijangkau }\end{array}$ & 276 & 92 & $\begin{array}{c}\text { Sangat } \\
\text { Setuju }\end{array}$ \\
$\begin{array}{l}\text { Tersedianya } \\
\text { halaman } \\
\text { parkir }\end{array}$ & 118 & 39,3 & Tidak Setuju \\
& & & \\
\hline & Total & 394 & 65,7 & Setuju \\
\hline
\end{tabular}

Tabel 10 menunjukkan bahwa dari seluruh indikator perilaku konsumen dalam keputusan pembelian Martabak Itang dari segi lokasi terletak pada angka 65,7\%. indikator yang memperoleh persentase perilaku konsumen yang tinggi adalah lokasi mudah dijangkau 92\%. Responden sangat setuju terhadap lokasi yang mudah pdijangkau, akan tetapi tempat parkir kurang memadai sehingga konsumen menyatakan tidak setuju terhadap tersedianya halaman parkir di Martabak Itang Pakowa Manado.

\section{Pelayanan}

Pelayanan adalah salah satu usaha yang dilakukan perusahaan untuk melayani konsumen dengan sebaik-baiknya, sehingga dapat memberikan kepuasan kepada konsumen, dan memenuhi kebutuhan serta keinginan konsumen, baik berupa produk barang atau jasa. Ada dua indikator aspek pelayanan untuk mengukur perilaku konsumen dalam keputusan pembelian Martabak Itang di Pakowa Manado yaitu kesopanan ketika berinteraksi dengan 
konsumen dan pelayanan tanggap dengan keluhan.

\section{Rekapitulasi Perilaku Konsumen Dalam Keputusan Pembelian Martabak Itang dari Segi Pelayanan}

Tabel 11 menunjukkan rekapitulasi terhadap jumlah skor pengambilan data pada perilaku konsumen dalam keputusan pembelian dari segi pelayanan.

Tabel 11. Rekapitulasi dari Total Skor dan Interpretasi Perilaku Konsumen Dalam Keputusan Pembelian Martabak Itang di Pakowa Manado dari Segi Pelayanan

\begin{tabular}{|c|c|c|c|c|}
\hline No & Pertanyaan & $\begin{array}{l}\text { Total } \\
\text { Skor }\end{array}$ & $\begin{array}{c}\text { Perilaku } \\
\text { Konsumen (\%) }\end{array}$ & aterpretasi \\
\hline 1. & $\begin{array}{l}\text { Kesopanan } \\
\text { ketika } \\
\text { berinteraksi } \\
\text { dengan } \\
\text { konsumen }\end{array}$ & 272 & 90,7 & $\begin{array}{l}\text { Sangat } \\
\text { Setuju }\end{array}$ \\
\hline 2. & $\begin{array}{l}\text { Tanggap dengan } \\
\text { keluhan }\end{array}$ & 259 & 86,3 & $\begin{array}{l}\text { Sangat } \\
\text { Setuju }\end{array}$ \\
\hline & Total & 531 & 88,5 & $\begin{array}{l}\text { Sangat } \\
\text { Setuju }\end{array}$ \\
\hline
\end{tabular}

Tabel 11 menunjukkan bahwa dari seluruh indikator perilaku konsumen dalam keputusan pembelian Martabak Itang dari segi pelayanan terletak pada angka $88,5 \%$. Artinya secara keseluruhan responden sangat setuju terhadap pelayanan yang ditawarkan dari Martabak Itang dan indikator yang memperoleh persentase perilaku konsumen yang tinggi adalah kesopanan ketika berinteraksi dengan konsumen yaitu 90,7\%.

\section{Rekapitulasi Perilaku Konsumen Dalam Keputusan Pembelian Martabak Itang dari Faktor Strategi Pemasaran}

Tabel 12 menunjukkan rekapitulasi terhadap jumlah skor pengambilan data pada perilaku konsumen dalam keputusan pembelian dari faktor strategi pemasaran.
Tabel 12. Rekapitulasi Total Skor, Perilaku Konsumen dan Interpretasi Dalam Keputusan Pembelian Martabak Itang di Pakowa Manado dari Faktor Strategi Pemasaran

\begin{tabular}{llccc}
\hline No. & Pertanyaan & $\begin{array}{c}\text { Total } \\
\text { Skor }\end{array}$ & $\begin{array}{c}\text { Perilaku } \\
\text { Konsumen }(\%)\end{array}$ & Interpretasi \\
\hline 1. & Produk & 858 & 95,3 & Sangat Setuju \\
2. & Harga & 549 & 91,5 & Sangat Setuju \\
3. & Promosi & 546 & 91 & Sangat Setuju \\
4. & Lokasi & 394 & 65,7 & Setuju \\
5. & Pelayanan & 531 & 88,5 & Sangat Setuju \\
\hline & Total & 2878 & 87,2 & Sangat Setuju \\
\hline
\end{tabular}

Sebagian besar pendapatan suatu perusahaan berasal dari produk, konsumen akan membeli produk tersebut untuk keperluannya sehari-hari, maupun untuk memenuhi kepuasannya. Saat ini banyak sekali perusahaan yang berpendapat bahwa konsumen lebih menyukai produk yang harganya relatif murah tetapi memiliki kualitas yang baik. Untuk itu pihak pengelola Martabak Itang harus mampu mepertahankan kualitas produk dari Martabak Itang baik dari segi cita rasa, variasi topping dan tekstur produk agar konsumen tetap menjadi pelanggan setia dalam membeli Martabak Itang di Pakowa Manado.

Rekapitulasi Perilaku Konsumen Martabak Itang di Pakowa Manado dari Faktor Individu, Lingkungan dan Strategi Pemasaran Dalam Keputusan Pembelian

Pada Tabel 13 menunjukkan rekapitulasi jumlah skor pengambilan data, indeks perilaku konsumen, dan interpretasi dalam keputusan pembelian dari faktor individu, lingkungan dan strategi pemasaran.

Tabel 13. Rekapitulasi Jumlah Skor Pengambilan Data, Indeks Perilaku Konsumen Dan Interpretasi Dari Konsumen Martabak Itang di Pakowa Manado

\begin{tabular}{clccc}
\hline No & Pertanyaan & $\begin{array}{l}\text { Total } \\
\text { skor }\end{array}$ & $\begin{array}{c}\text { Indeks Perilaku } \\
\text { Konsumen (\%) }\end{array}$ & Interpretasi \\
\hline 1. & Individu & 341 & 53,7 & Netral \\
2. & Lingkungan & 442 & 73,7 & Setuju \\
3. & Strategi Pemasaran & 2878 & 87,2 & Sangat Setuju \\
\hline & Total & 3661 & 81,3 & Sangat Setuju \\
\hline
\end{tabular}


Jumlah skor ideal untuk keseluruhan pertanyaan $=4500$ (Sangat Setuju), jumlah skor terendah $=900$ (Sangat Tidak Setuju). Berdasarkan data yang dihimpun dari 15 pertanyaan yang diajukan kepada 60 responden, maka diperoleh total skor 3661 dengan indeks tanggapan konsumen sebagai berikut:

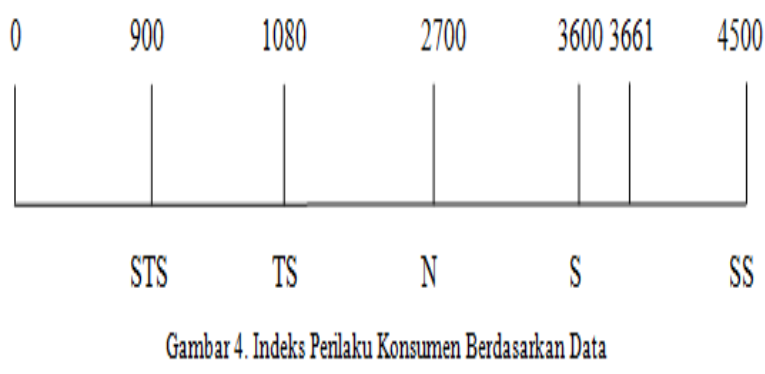

Secara persentase, indeks perilaku konsumen terletak pada:

$$
\text { Perilaku Konsumen }=\frac{3661}{4500} \times 100 \%=81,3 \%
$$

Dengan indeks perilaku konsumen yaitu:

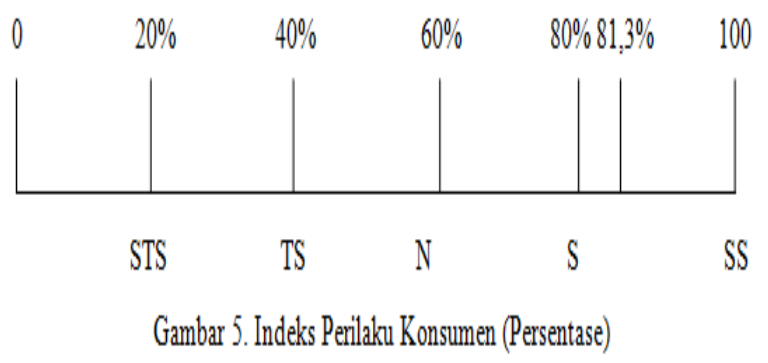

Berdasarkan hasil analisis mengunakan skala likert, maka dapat diketahui bahwa indeks perilaku konsumen Martabak Itang di Pakowa Manado dari faktor individu, lingkungan dan strategi pemasaran berada pada titik $81,3 \%$ termasuk dalam kategori sangat setuju. Sebanyak 15 indikator pertanyaan tentang perilaku konsumen dalam keputusan pembelian baik dari faktor individu, lingkungan dan strategi pemasaran.

Masalah utama berada pada faktor strategi pemasaran dari segi lokasi yang dimana konsumen merasa tidak setuju dengan tersedianya halaman parkir. Berdasarkan hasil wawancara dengan pelanggan, konsumen berharap agar memperbaiki tempat parkir yang ada di lokasi Martabak Itang pakowa Manado agar konsumen tidak parkir sembarangan.

Dari 3 faktor tersebut strategi pemasaran dari segi produk yang memiliki persentase perilaku konsumen yang paling tinggi yaitu sebesar 95,5\%. Hal ini menunjukkan bahwa konsumen merasa sangat setuju terhadap seluruh indikator produk yang ditawarkan oleh pihak Martabak Itang.

\section{KESIMPULAN DAN SARAN}

\section{Kesimpulan}

Kebutuhan dan motivasi sebagai pengukur pilihan konsumen tidak mempengaruhi konsumen untuk membeli produk Martabak Itang. Faktor lingkungan yang diukur berdasarkan indikator keluarga dan teman mempengaruhi keputusan pembelian. Sedangkan faktor strategi pemasaran yang diukur berdasarkan produk, harga, promosi, lokasi, pelayanan mempengaruhi keputusan pembelian.

\section{Saran}

Saran yang dapat diberikan berdasarkan hasil penelitian ini yaitu pihak Martabak Itang harus dapat mempertahankan strategi pemasaran dari segi produk, harga, promosi dan pelayanan yang selama ini dinilai baik oleh konsumen. Selain itu dari segi lokasi pihak pengelola Martabak Itang harus meperbaiki tempat parkir yang ada di lokasi Martabak Itang Pakowa Manado.

\section{DAFTAR PUSTAKA}

Bachrul, H. 2013. Bisakah Wisata Kuliner Indonesia Dijual. http: //www. sinarharapan. co.id. 1 Februari 2018. 
Gunawan, H. 2011. Kuliner akan Dimasukkan dalam Industri Kreatif. http:// www. tribunnews. Com. 3 Februari 2018.

Schiffman, L. dan L. Kanuk. 2008. Perilaku Konsumen. Edisi Ketujuh. PT Indeks. Jakarta.

Sunyoto, D. 2012. Konsep Dasar Riset Pemasaran dan Perilaku Konsumen. CAPS. Yogyakarta. 